\title{
Atrazine-Induced Chlorosis in Synechococcus elongatus Cells
}

Óscar González-Barreiro, Carmen Rioboo, Ángeles Cid, Concepción Herrero ${ }^{1}$

Archives of Environmental Contamination and Toxicology, April 2004, Volume 46, Issue 3 , pp 301-307

Received: 20 August 2002/Accepted: 11 August 2003

DOI: 10.1007/s00244-003-2149-z

\begin{abstract}
.
The effects of a widely used herbicide, atrazine, on the freshwater cyanobacterium Synechococcus elongatus were studied. The cyanobacteria were exposed to varying concentrations of atrazine $(0.025,0.05,0.1,0.25$, and $0.75 \mu \mathrm{M})$ for $96 \mathrm{~h}$. Different parameters such as growth, autofluorescence of chlorophyll $a$, pigment content, volume, and internal granularityof the cells were determined daily. Differences were detected between cultures with and cultures without atrazine for the parameters analyzed. Atrazine exposure induced the process of chlorosis in cyanobacterial cells, given that this herbicide has an effect on photosynthesis, chlorotic subpopulations having low values of chlorophyll a autofluorescence. More unpigmented subpopulations (chlorotic) appeared as the atrazine concentration increased and better growth rates resulted. Atrazine also induced changes in cell volume and internal granularity, these being most apparent after $48 \mathrm{~h}$ of exposure and in cultures with higher atrazine concentrations $(0.25$ and $0.75 \mu M)$.
\end{abstract}

Atrazine, 6-chloro- $N^{2}$-ethyl- $N^{4}$-isopropyl-1,3,5-triazine-2,4-diamine, is one of the most commonly used herbicides, applied to control the growth of grasses and weeds. Photosynthesis is the primary target in over $50 \%$ of commercial herbicides. Attacking this target is effective given that photosynthesis is the main system of energy production in most vegetal cells. Since atrazine is a triazine herbicide, its biochemical action involves displacing plastoquinone (QB) from its binding site with D1 protein in photosystem II (PS II) (Singh et al. 1997), leading to an energy unbalance in affected vegetal cells, due to the inhibition of electron transport.

\footnotetext{
${ }^{1}$ Laboratorio de Microbiología, Departamento Biología Celular y Molecular, Facultad de Ciencias, Universidade da Coruña, Campus da Zapateira s/n, 15071 A Coruña, Spain
} 
Given the wide use of these herbicides, they appear more and more in numerous freshwater systems at concentrations higher than those legally permitted, affecting nontarget photosynthetic organisms, including microalgae and cyanobacteria, which are at the base of trophic aquatic chains (Forrest 1990).

Most microalgae are able to generate resting forms under stress conditions. It has been reported that cyanobacteria enter a new physiological state called chlorosis under conditions of nutrient deprivation. The chlorosis state consists of a low level of residual photosynthesis, in which both photosystems (PS I and PS II) gradually lose their activity, and chlorophyll and phycobiliproteins are degraded to reach a residual content (Sauer et al. 2001).

In the present study, the process of chlorosis, provoked in a nonobligate photoautotrophic strain of the unicellular cyanobacterium Synechococcus elongatus exposed to the herbicide atrazine, was studied using flow cytometry-based methods, since these have been useful in other cytotoxicity studies in microalgae (Cid et al. 1995; Franqueira et al. 2000).

\section{Materials and Methods}

\section{Culture Conditions}

Synechococcus elongatus (Nägeli) Nägeli (Cyanophyceae) taken from the Culture Collection of Algae and Protozoa (CCAP; Cumbria, UK; strain 1479/1A) was cultured in autoclaved Bristol medium (Brown et al. 1967). Different atrazine concentrations $(0.025,0.05,0.1,0.25,0.75 \mu \mathrm{M})$ were assayed. Atrazine stock $(500 \mu M)$ was prepared by dissolving granulated herbicide (Riedel de Haën; MW 215.69) in pure methanol. All cultures were carried out in Pyrex glass bottles containing $400 \mathrm{ml}$ of medium. Cultures without herbicide were included as a control.

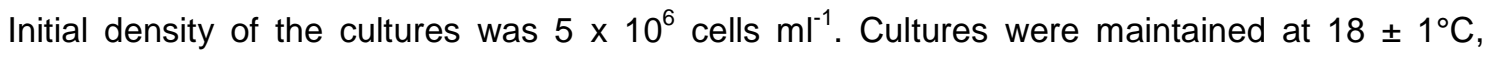
illuminated with $68.25 \mu \mathrm{mol}$ photon $\mathrm{m}^{-2} \mathrm{~s}^{-1}$, with a dark:light cycle of $12: 12 \mathrm{~h}$, and continuously aerated at a rate of $10 \mathrm{~L} \mathrm{~min}^{-1}$, for $96 \mathrm{~h}$. All experiments were carried out in duplicate.

\section{Flow Cytometry Determinations}

Signals of forward scatter (FSC), side scatter (SSC), and red fluorescence (fluorescence of chlorophyll a) were recorded daily in a Coulter Epics XL4 flow cytometer equipped with an argon-ion excitation laser ( $488 \mathrm{~nm}$ ), detectors of forward and side scatter, and four fluorescence detectors corresponding to four wavelength intervals: FL1 (488-550 nm), FL2 (550-600 nm), FL3 $(600-645 \mathrm{~nm})$, and FL4 $(>645 \mathrm{~nm})$. Since the FSC signal can be correlated with the volume of a cell or particle, and the SSC signal with internal cell granularity (Shapiro 1995), aliquots of microalgal cultures were analyzed by flow cytometry to study potential changes in cell volume and internal granularity. 
Red fluorescence of chlorophyll a (FL4; 645-675 nm) was represented as histograms to separate nonphototrophic chlorotic subpopulations from phototrophic pigmented populations containing a normal chlorophyll a content, to allow the analysis of other parameters of both subpopulations separately. Data for autofluorescence were expressed as a percentage of the signal of control cells according to the equation of Reader et al. (1993),

$$
\% F^{F\llcorner 4}=100-\left[100 \times\left(I_{\text {control }}{ }^{\mathrm{FL} 4}-I_{\text {pesticide }}{ }^{\mathrm{FL} 4}\right) / I_{\text {control }}{ }^{\mathrm{FL} 4}\right]
$$

where $\% f^{F L 4}$ is the percentage of the autofluorescence signal of $S$. elongatus cells, $I_{\text {control }}{ }^{\mathrm{F} 4}$ is the mean of the autofluorescence signal of control cells, and $I_{\text {pesticide }}{ }^{\mathrm{FL} 4}$ is the mean of the autofluorescence signal of atrazine-treated cells.

\section{Growth Measurement}

Growth of microalgal cultures with different atrazine concentrations was determined by counting culture aliquots.

To exclude nonalgal particles, red fluorescence histograms were used as a gate. This gate does not exclude algal particles showing a low chlorophyll a content, like chlorotic cells, because these forms maintain a residual photosynthesis level detectable by flow cytometry. Growth of subpopulations with a normal chlorophyll content (phototrophic subpopulation) and chlorotic subpopulations (nonphototrophic subpopulation) were analyzed separately, due to the differences in the red fluorescence, detectable by flow cytometry.

Growth rate, expressed as doublings day ${ }^{-1}$, was calculated using the following formula:

$$
\mu=\left[\left(\ln \left(\mathrm{N}_{\mathrm{t}}\right)-\left(\ln \left(\mathrm{N}_{0}\right)\right] / \ln 2\left(\mathrm{t}-\mathrm{t}_{0}\right)\right.\right.
$$

where $N$ is the cell density at time $t$ and $N_{0}$ is the cell density at time 0 .

Growth data were fitted by a nonlinear regression with the Wizard regression of Sigma-Plot software.

\section{Determination of Pigment Content}

Contents of chlorophyll a, carotenoids, and phycobiliproteins after 48 and $96 \mathrm{~h}$ of culture were determined using a Shimadzu UV-160 spectrophotometer. For chlorophyll $a$ and carotenoids, cells were collected by centrifugation and pigments extracted in pure methanol (100\%). For better extraction, cyanobacterial cell suspensions were sonicated with short pulses of ultrasounds at $4^{\circ} \mathrm{C}$ in the dark. All determinations were carried out in triplicate. Equations used to calculate the concentrations of these pigments were those proposed by Sukenik et al. (1988).

The method for phycobiliprotein extraction described by Betancourt (1997) was improved. Cells were collected by centrifugation and resuspended in a CaCl2 $\left(20 \mathrm{~g} \mathrm{~L}^{-1}\right)$ solution. For better 
extraction, cells were successively frozen at $-80^{\circ} \mathrm{C}$ and thawed at $40^{\circ} \mathrm{C}$ four times and sonicated with short pulses of ultrasounds in darkness for $1 \mathrm{~min}$. Phycocyanin and alophycocyanin concentrations were calculated using the equations of Siegelman and Kycia (1978).

Statistical analysis of data was by one-way analysis of variance (ANOVA), and when significant differences were observed, the means were compared by multiple-range Duncan test, at a significance level of $0.05(p<0.05)$.

\section{Results}

\section{Chlorophyll a Fluorescence}

All cultures exposed to the herbicide developed chlorotic populations, which were more abundant as the herbicide concentration increased, these becoming the main population at the highest concentrations assayed, 0.25 and $0.75 \mu M$ (Table 1).

After $48 \mathrm{~h}$ of atrazine exposure, pigmented cells in cultures with the lower concentrations of atrazine assayed $(0.025-0.1 \mu \mathrm{M})$ showed autofluorescence values similar to those of control cells, whereas pigmented cells in cultures exposed to the higher concentrations $(0.25$ and 0.75 $\mu M$ ) presented higher values, 115.96 and $138.53 \%$, respectively (Table 2). However, after $96 \mathrm{~h}$, pigmented cells in all cultures treated with atrazine presented autofluorescence values about $50 \%$ lower than those of control cells (Table 2 ).

Autofluorescence of chlorotic cells presented basal values for all cultures where they appeared (Fig. 1).

Table 1. Cell densities $\left(x 10^{6}\right.$ cells $\mathrm{ml}^{-1}$ ) and percentage of pigmented and chlorotic subpopulations of Synechococcus elongatus differentiated by flow cytometry, after 48 and $96 \mathrm{~h}$ of herbicide exposure, and in cultures with different atrazine concentrations
$48 \mathrm{~h}$

\begin{tabular}{llll}
\cline { 2 - 4 } & $\begin{array}{l}\text { Cell } \\
\text { density }\end{array}$ & $\begin{array}{l}\% \\
\text { pigmented } \\
\text { cells }\end{array}$ & $\begin{array}{l}\% \\
\text { chlorotic } \\
\text { cells }\end{array}$ \\
\hline Control & $27.7 \pm 1.2$ & 99.1 & 0.9 \\
0.025 & $26.3 \pm 0.6$ & 97.04 & 2.95 \\
0.05 & $19.8 \pm 1.1$ & 95.07 & 4.93 \\
0.1 & $16.4 \pm 0.5$ & 96.05 & 3.95 \\
0.25 & $9.3 \pm 0.1$ & 91.04 & 8.96 \\
0.75 & $6.2 \pm 0.3$ & 90.62 & 9.38 \\
& 96 h & & \\
\cline { 2 - 4 } & & $\%$ & $\%$ \\
& & pigmented & chlorotic \\
& Cell density & cells & cells \\
\cline { 2 - 4 } & $112.7 \pm 1.6$ & 99.4 & 0.6 \\
& $100.1 \pm 8.9$ & 98.11 & 1.89 \\
& $75.5 \pm 3.4$ & 96.2 & 8.52 \\
& $57.1 \pm 2.1$ & 91.48 & 47.12 \\
& $39.2 \pm 3.1$ & 52.88 & 88.95
\end{tabular}


Table 2. Chlorophyll a autofluorescence of pigmented and chlorotic cells of Synechococcus elongatus cultured at different atrazine concentrations, after 48 and 96 $\mathrm{h}$ of exposure ${ }^{2}$

\begin{tabular}{llllll} 
& $48 \mathrm{~h}$ & & & $96 \mathrm{~h}$ & \\
\cline { 2 - 3 } \cline { 5 - 6 } & $\begin{array}{l}\text { Pigmented } \\
\text { cells }\end{array}$ & $\begin{array}{l}\text { Chlorotic } \\
\text { cells }\end{array}$ & & $\begin{array}{l}\text { Pigmented } \\
\text { cells }\end{array}$ & $\begin{array}{l}\text { Chlorotic } \\
\text { cells }\end{array}$ \\
\hline Control & 100 & - & & 100 & - \\
0.025 & 106.78 & 2.42 & & 64.71 & 1.22 \\
0.05 & 89.72 & 2.41 & & 53.77 & 1.30 \\
0.1 & 95.41 & 2.48 & & 54.24 & 1.29 \\
0.25 & 115.96 & 2.44 & & 50.47 & 1.19 \\
0.75 & 138.53 & 2.41 & & 58.58 & 1.23
\end{tabular}

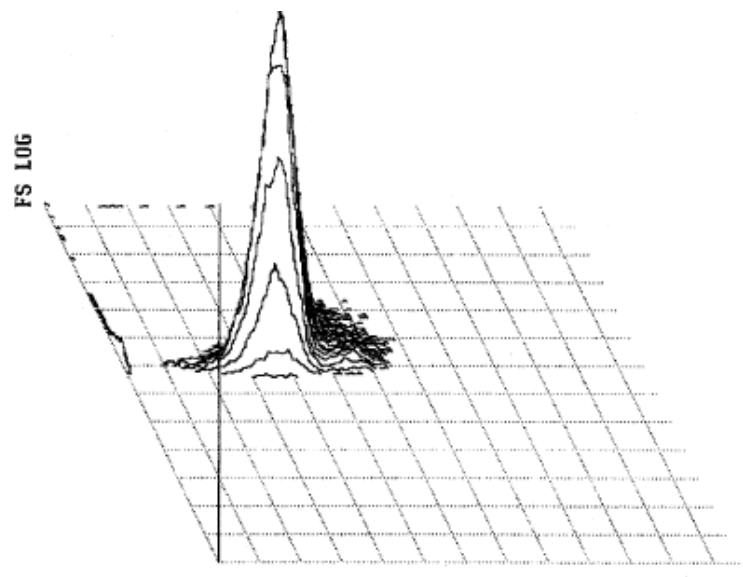

FL.4 L.OG

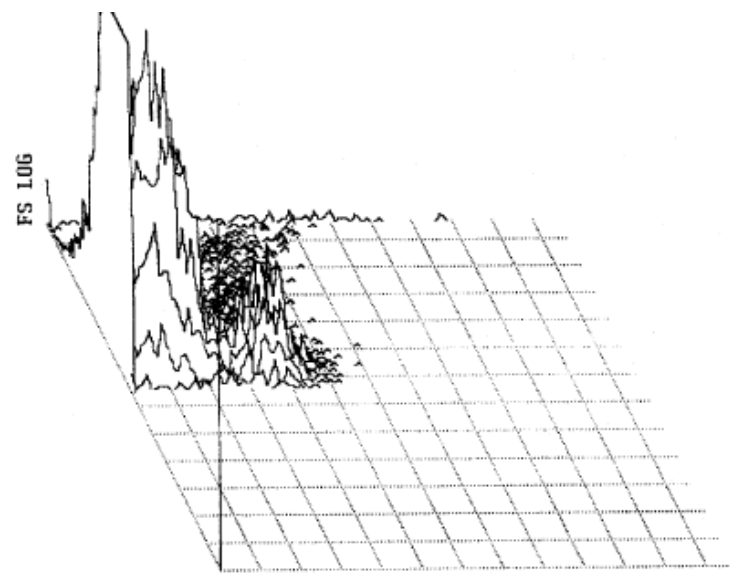

FL4 LOG

Fig. 1. Histograms for chlorophyll a autofluorescence and forward scatter in control cultures (left) and in $0.75 \mu \mathrm{M}$ atrazine cultures (right), after $96 \mathrm{~h}$ of exposure

\section{Growth}

Atrazine affected the growth of the freshwater cyanobacterium Synechococcus elongatus at all concentrations assayed (Table 3).

More chlorotic subpopulations were detected in atrazinetreated cultures than in control cultures (Table 1). The percentage of chlorotic cells increased as the atrazine concentration increased, reaching values of 47.12 and $88.95 \%$ of the total cyanobacterial population in cultures of $S$. elongatus exposed to 0.25 and $0.75 \mu \mathrm{M}$, respectively, after $96 \mathrm{~h}$ (Table 1). In cultures with atrazine concentrations of 0.025 to $0.1 \mu \mathrm{M}$, the percentage of chlorotic cells did not surpass $4.93 \%$ after $48 \mathrm{~h}$ of atrazine exposure, and $8.52 \%$ after $96 \mathrm{~h}$ (Table 1). Chlorotic cells showed higher growth rates than pigmented cells in all cultures with atrazine (Table 3). After $48 \mathrm{~h}$ of herbicide exposure, maximum growth rates were observed for chlorotic cells in cultures of 0.025 $\mu M$ atrazine. After $96 \mathrm{~h}$ of atrazine exposure, maximum growth rate (2.90 doublings day $\left.{ }^{-1}\right)$ for chlorotic cells was observed in cultures with the highest herbicide concentration assayed $(0.75$

\footnotetext{
${ }^{2}$ Data are expressed as the percentage of the signal of control cells according to the equations of Reader et al. (1993).
} 
$\mu M$ ) (Table 3). Higher growth rates for chlorotic cells were only found in cultures with higher atrazine concentrations $(0.25$ and $0.75 \mu \mathrm{M})$, where the chlorotic subpopulation was the main population after $96 \mathrm{~h}$ of herbicide exposure (Table 3 ).

Minimum growth rate in pigmented cells was observed at the highest atrazine concentration assayed, $0.75 \mu M$ (Table 3).

After $48 \mathrm{~h}$ of atrazine exposure, the lowest atrazine concentration $(0.025 \mu \mathrm{M})$ assayed did not provoke significant differences in growth rate of pigmented cells (1.24 doublings day $\left.{ }^{-1}\right)$ with respect to cells in control cultures (1.23 doublings day ${ }^{-1}$ ); however, differences were observed after $96 \mathrm{~h}$ of atrazine exposure when the growth rate of these cells $\left(0.75\right.$ doublings day $\left.^{-1}\right)$ was lower than that observed in control cultures $\left(0.85\right.$ doublings day $\left.^{-1}\right)($ Table 3$)$. In the remaining cultures exposed to higher atrazine concentrations $(0.05-0.75 \mu \mathrm{M})$, pigmented cells showed significant differences, with lower growth rates than cells in control cultures $(p<0.05)$ (Table 3$)$, after 48 and $96 \mathrm{~h}$ of atrazine exposure.

The most common parameter used in toxicity tests is the $\mathrm{EC}_{50}$, the concentration of tested substance which provokes $50 \%$ of the expected effect, in this case, a reduction in the cell density of pigmented subpopulations by $50 \%$ with respect to these cells in control cultures, constituted only by pigmented cells. The most appropriate statistical method to obtain the $\mathrm{EC}_{50}$ value is the graphic interpolation. Data at 48 and $96 \mathrm{~h}$ were fitted to a sigmoidal curve whose formula was

$$
y=a /\left(1+e^{-(x-x / b)}\right)
$$

where $y$ is the percentage of inhibition of growth of pigmented subpopulations with respect to the control (cultures without atrazine), $x$ is the herbicide concentration in $\mu M$, and the three parameters for this function determine the highest value observed $(a)$, the width of the transition (b), and the $x$-value at which the function is $50 \%$ of the amplitude of the function ( $x 0$, closely related with $\mathrm{EC}_{50}$ ).

Values of $\mathrm{EC}_{50}$ for atrazine for $S$. elongatus calculated by graphic interpolation with functions calculated as described above were $0.11 \mu M$ after $48 \mathrm{~h}$ and $0.23 \mu M$ after $96 \mathrm{~h}$ (Table 3).

Table 3. Growth rates of pigmented and chlorotic subpopulations of Synechococcus elongatus after 48 and $96 \mathrm{~h}$ of herbicide exposure ${ }^{3}$

\begin{tabular}{|c|c|c|c|c|c|}
\hline & \multicolumn{2}{|l|}{$\mu, 48 \mathrm{~h}$} & \multicolumn{2}{|l|}{$\mu, 96 \mathrm{~h}$} & \multirow[b]{2}{*}{$\mathrm{EC}_{50}(\mu M)^{\mathrm{a}}$} \\
\hline & Pigmented cells & Chlorotic & Pigmented cells & Chlorotic & \\
\hline Control & 1.23 & 1.12 & 0.85 & 0.52 & $48 \mathrm{~h}, 0.11$ \\
\hline 0.025 & 1.24 & 2.19 & 0.75 & 0.23 & \\
\hline 0.05 & 0.84 & 1.25 & 0.58 & 0.09 & \\
\hline 0.1 & 0.74 & 1.52 & 0.78 & -0.05 & $96 \mathrm{~h}, 0.23$ \\
\hline 0.25 & 0.18 & 1.89 & 1.16 & 1.34 & \\
\hline 0.75 & 0.04 & 1.20 & -0.19 & 2.90 & \\
\hline
\end{tabular}

\footnotetext{
${ }^{3}$ EC50 values at 48 and $96 \mathrm{~h}$ of atrazine exposure
} 


\section{Chlorophyll a and Total Carotenoids}

After $48 \mathrm{~h}$ of atrazine exposure, the cell content in chlorophyll $a$ and carotenoids increased as the herbicide concentration increased (Fig. 2). Maximum chlorophyll a (0.38 pg cell ${ }^{-1}$ ) and carotenoid contents $\left(0.21 \mathrm{pg} \mathrm{cell}{ }^{-1}\right)$ were obtained in cultures with the highest atrazine concentration studied, $0.75 \mu \mathrm{M}$, whereas in control cultures these values were 0.21 and $0.14 \mathrm{pg}$ cell $^{-1}$, respectively (Fig. 2).

After $96 \mathrm{~h}$ of culture, maximum pigment content $\left(0.37 \mathrm{pg} \mathrm{cell}^{-1}\right.$ for chlorophyll $\mathrm{a}$ and $0.18 \mathrm{pg} \mathrm{cell}^{-1}$ for total carotenoids) was obtained in control cultures, while pigment content decreased in atrazine cultures (Fig. 3). Minimum cellular content of both pigments was observed in cultures with $0.75 \mu \mathrm{M}$ atrazine, contents of chlorophyll a being $0.09 \mathrm{pg} \mathrm{cell}^{-1}$ and of carotenoids $0.05 \mathrm{pg}$ cell $^{-1}$ (Fig. 3).

\section{Phycobiliproteins}

The pattern observed for cell content for phycocyanin and alophycocyanin was similar to that observed for chlorophyll $a$ and carotenoids (Figs. 2 and 3). After $48 \mathrm{~h}$ of atrazine exposure, the maximum contents of both phycobiliproteins, 0.11 and $0.14 \mathrm{pg}$ for phycocyanin $\mathrm{cell}^{-1}$, respectively, and 0.036 and $0.038 \mathrm{pg}$ for alophycocyanin cell $^{-1}$, were obtained in cultures exposed to the higher concentrations assayed $(0.25$ and $0.75 \mu M)$ (Fig. 2). Concentrations of phycobiliproteins in control cultures after $48 \mathrm{~h}$ were 0.05 and $0.02 \mathrm{pg} \mathrm{cell}^{-1}$ for both pigments, respectively (Fig. 2).

Fig. 2. Contents of chlorophyll $a$,

carotenoids, phycocianin, and alophycocyanin (pg $\mathrm{cell}^{-1}$ ) in Synechococcus elongatus cultures, cultured in different atrazine concentrations, and after $48 \mathrm{~h}$ of exposure

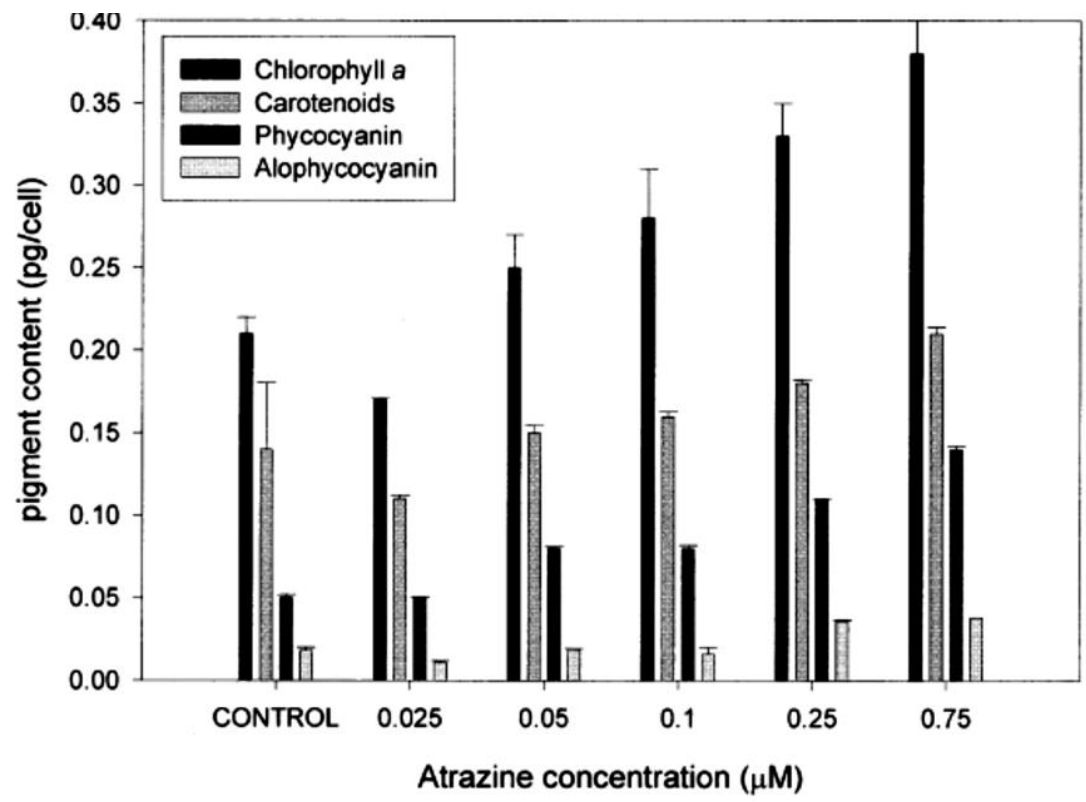


Fig. 3. Contents of chlorophyll $a$,

carotenoids,

phycocyanin, and

alophycocyanin (pg cell ${ }^{-1}$ )

in Synechococcus

elongatus cultures,

cultured in different

atrazine concentrations,

and after $96 \mathrm{~h}$ of

exposure

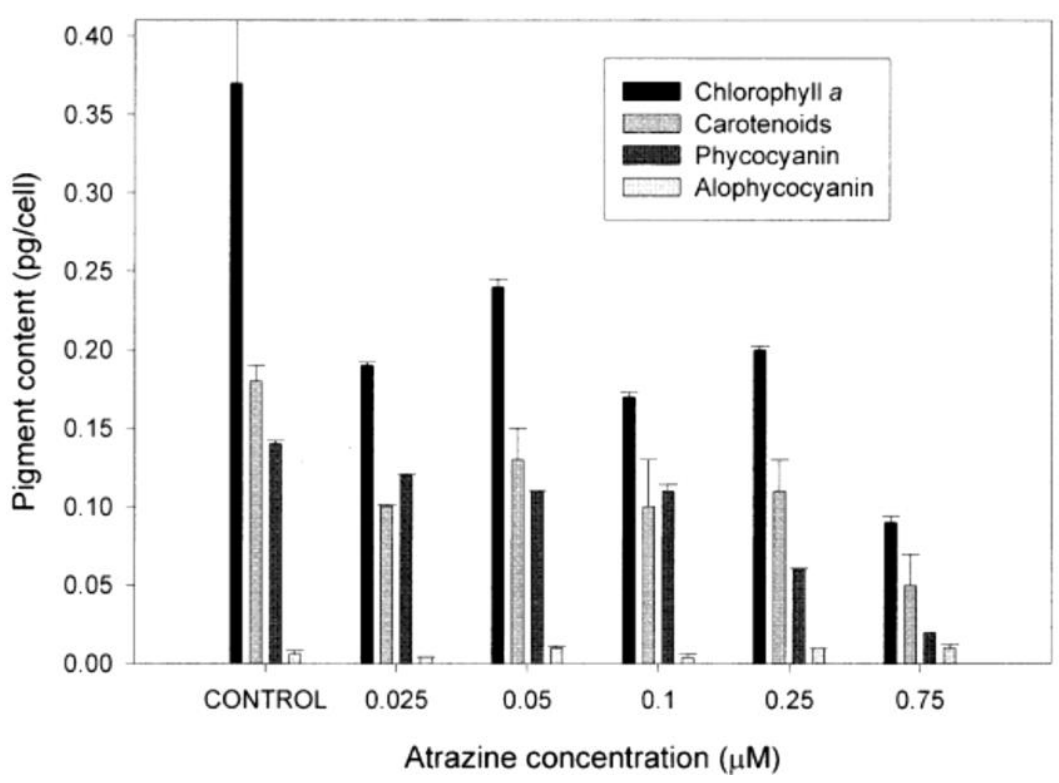

After $96 \mathrm{~h}$ of culture, maximum content of phycobiliproteins, $0.14 \mathrm{pg} \mathrm{cell}^{-1}$ for phycocyanin and $0.012 \mathrm{pg} \mathrm{cell}^{-1}$ for alophycocyanin, was obtained in control cultures, whereas minimum contents were obtained in cultures exposed to the highest atrazine concentration, $0.75 \mu \mathrm{M}$, with values of 0.02 and $0.01 \mathrm{pg} \mathrm{cell}^{-1}$ for phycocyanin and alophycocyanin, respectively (Fig. 3).

\section{Cell Volume and Internal Cell Granularity}

These parameters were determined separately in chlorotic and pigmented cells. Volume (FSC signal) of pigmented cells only was affected by the highest atrazine concentration assayed ( 0.75 $\mu M)$. In the remaining cultures, volume was maintained constant and there were no significant differences with respect to control cells. Pigmented cells exposed to $0.75 \mu \mathrm{M}$ atrazineshowed a slightly higher cell volume than control cells (Fig. 4).

Chlorotic cells presented a higher cell volume than pig mented cells in all cultures treated with atrazine in the first $48 \mathrm{~h}$. After this time, chlorotic cell volume decreased to values similar to those of control cells after $96 \mathrm{~h}$ of atrazine exposure (Fig. 4).

Internal cell granularity (SSC signal) of pigmented cells did not show significant differences in time with respect to control cells. Only in cultures exposed to $0.75 \mu \mathrm{M}$ atrazine, the SSC signal was maximum during the first $72 \mathrm{~h}$, but after $96 \mathrm{~h}$ there were no significant differences with respect to the cells of the remaining cultures exposed to atrazine. Control cultures reached maximum values after $96 \mathrm{~h}$ of culture (Fig. 5).

Regarding chlorotic cells, their internal granularity was higher than that of pigmented and control cells during the first $48 \mathrm{~h}$ of exposure and for all atrazine concentrations assayed. After this time internal granularity of the chlorotic populations was lower than that obtained for the pigmented cells (Fig. 5). 


\section{Discussion}

The process of chlorosis as a response to adverse environmental conditions like nutrient deprivation was previously described (Collier and Grossman 1992; Sauer et al. 2001). This process is not accompanied by loss in cell viability; it is only a temporary state that cells can leave when environmental conditions change. Other stress sources, as the presence of pesticides which act on the photosynthesis, like triazine herbicides, could provoke similar situations. Probably, not all chlorosis are the same; previous works describe that it could depend on the kind of nutrient deprivation (Collier and Grossman 1992), and although the final result is the same, the evolution of this process is different. The chlorosis process described for Synechococcus PCC 7942 in cases of nutrient deprivation has three general phases: first, the rapid degradation of phycobilisomes; second, a gradual loss of chlorophyll a and proteins; and, finally, a loss of all cell pigmentation, leading to the resting cell formation (Sauer et al. 2001). These phases can be more or less fast depending on the stress factor. In the present work, using a nonobligate photoautotrophic cyanobacterium, it was observed that atrazine induced a chlorotic state but did not lead to the formation of resting cells; the "chlorotic cells" induced by atrazine were able to grow (Tables 1 and 3 ).

Taking into account the autofluorescence determined by flow cytometry, Synechococcus elongatus cultures exposed to atrazine presented two well-differentiated populations by autofluorescence in the flow cytometer (Fig. 1). One population showed similar flow cytometric characteristics to those observed in control cultures ("pigmented cells") (Table 2), and the other gave basal autofluorescence values with respect to control cells ("chlorotic cells") (Table 2). The results obtained reveal that all atrazine concentrations assayed provoked the development of chlorotic subpopulations that were able to grow, indicative of an active metabolism. Chlorotic cells appeared throughout the $48 \mathrm{~h}$ after atrazine exposure in all cultures containing pesticide. After this 48-h period, growth rates of these new metabolic forms increased exponentially, reaching the highest cell density in cultures exposed to $0.75 \mu M$ atrazine (Table 1 ).

Pigmented cells showed lower growth rates than chlorotic cells, as the atrazine concentration increased (Table 3), leading to a decrease in their percentage in cultures with herbicide (Table 1).

It seems that $S$. elongatus cells under the stress induced by atrazine would change their photoautotrophic metabolism, inefficient under these conditions, to a heterotrophic metabolism. It has been reported before that some green microalgal species could metabolize simazine and incorporate it into their own proteins (Kruglov 1970). One possible explanation to the results obtained in this study, could be that autotrophic cells(pigmented cells) adapted their metabolism during the 48-h period after atrazine exposure. Pigmented cells recovered their growth rates after $72 \mathrm{~h}$ of atrazine exposure (Table 3), perhaps due to the fact that previous generations of cells took in pesticide from the medium; since atrazine is an organic molecule, heterotrophic subpopulations (chlorotic cells) possibly use it as an organic carbon source. Pigmented cells 
(autotrophic cells) from cultures with the highest concentration assayed, $0.75 \mu \mathrm{M}$, could not recover their growth rates (Table 3); probably this concentration is too high and cyanobacterial cells could not take up and metabolize enough herbicide to allow the growth of autotrophic cells. In any case, EC50 results at $96 \mathrm{~h}$ showed that the herbicide was still effective after this time and chlorotic cells showed higher growth rates than those of pigmented cells in cultures with herbicide (Table 3).

Fig. 4. Evolution of cell volume, correlated with forward scatter signal obtained by flow cytometry (AU; arbitrary units) of control culture cells and pigmented and chlorotic cells, in $0.75 \mu \mathrm{M}$ atrazine cultures, during $96 \mathrm{~h}$

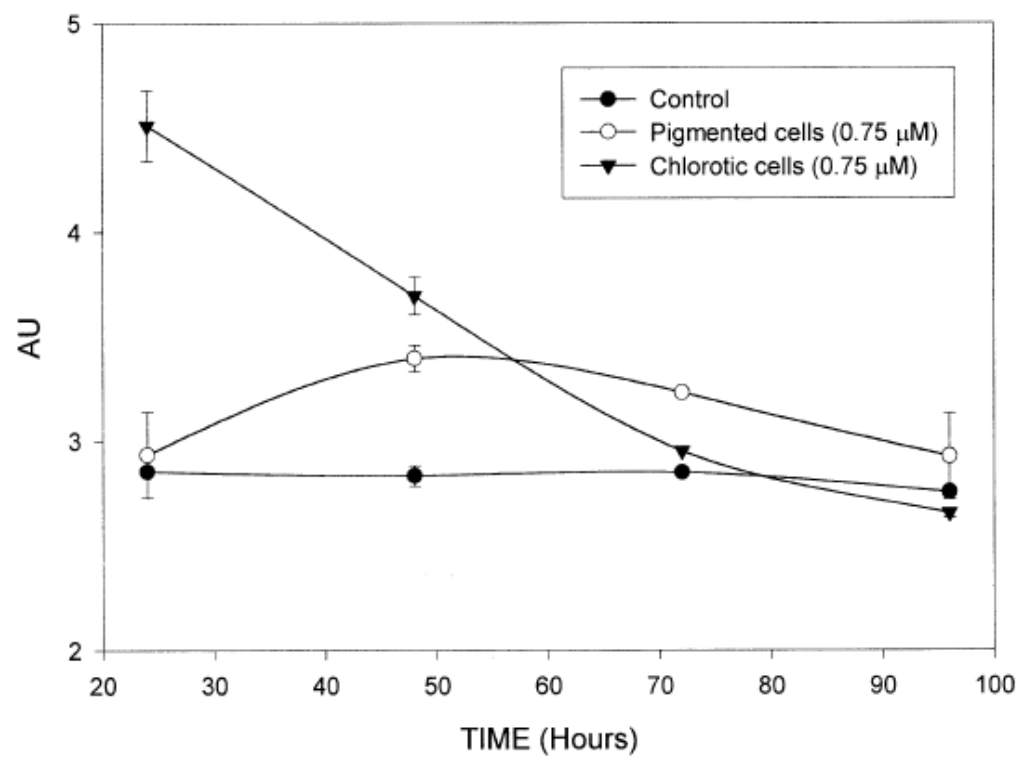

Fig. 5. Evolution of internal cell granularity, correlated with side scatter signal obtained by flow cytometry (AU; arbitrary units) of control culture cells and pigmented and chlorotic cells, in $0.75 \mu M$ atrazine cultures, during $96 \mathrm{~h}$

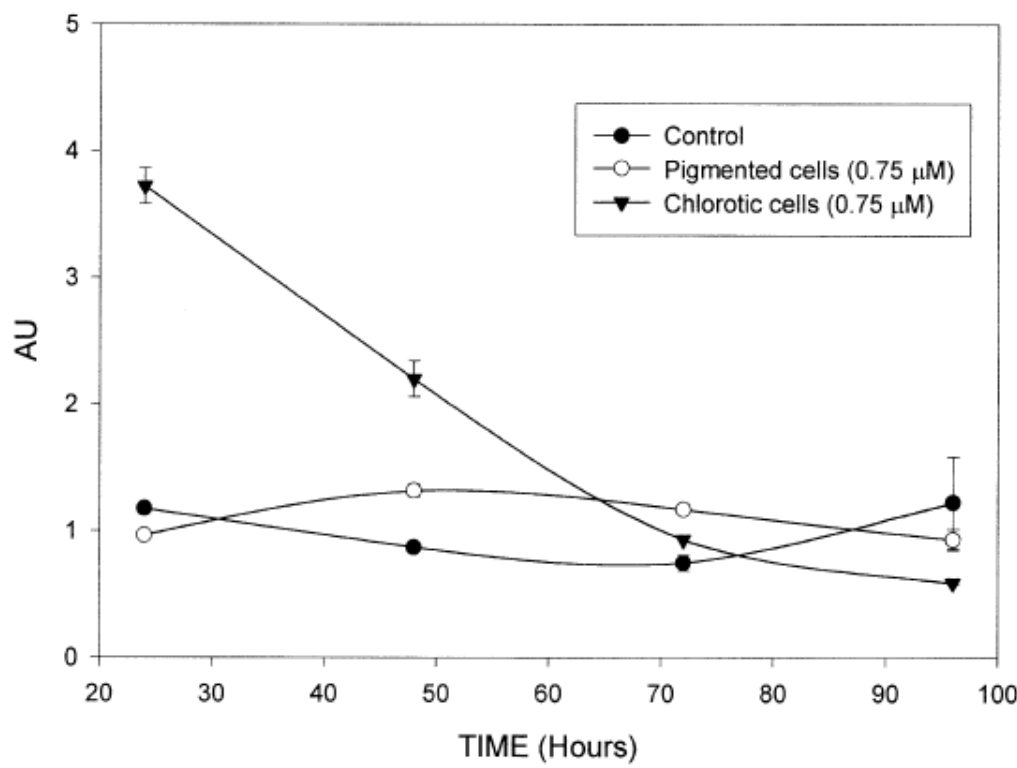

A secondary effect of triazines is the photooxidation of photosynthetic pigments. Pigment content per cell was higher when atrazine concentration increased, after $48 \mathrm{~h}$ of atrazine exposure (Fig. 2). However, after $96 \mathrm{~h}$ pigment content was lower in atrazine-treated cultures than in control cultures (Fig. 3). Chlorophyll $a$, carotenoids, and phycobiliproteins showed the same temporal evolution pattern. These results are corroborated by those obtained by flow cytometry, and the decrease in chlorophyll a fluorescence was detected in cultures with 
atrazine. Chlorotic cells presented low values of this pigment (basal content) in all cultures where they appeared. Pigmented cells of cultures with atrazine showed values of chlorophyll $a$ fluorescence slightly lower than pigmented cells of control cultures (Fig. 1).

It has been reported that phycobiliproteins could have a secondary function as an intracellular reservoir of organic nitrogen in deficit situations (Lau et al. 1977); in chlorotic cells this degradation could be an important source of organic nitrogen, contributing to the heterotrophic metabolism induced by atrazine exposure.

These results can be related with those obtained by flow cytometry about cell volume and intracellular granularity; after $48 \mathrm{~h}$ of exposure, cells cultured with atrazine (chlorotic and pigmented cells) showed higher cell volumes and internal granularity than cells of control cultures (Figs. 4 and 5). Cells exposed to atrazine have an energy deficit and could not finish their division; hence, short chains of two or three cells appear.

Cells that have active growth appear as individual cells. Chain formation is typical of a stationary state, when the concentration of nutrients is deficient, and cell volume signal is higher during this phase than in the logarithmic phase. Therefore, high internal granularity of chlorotic cells after $48 \mathrm{~h}$ of herbicide exposure, especially in cultures of $0.75 \mu \mathrm{M}$, could be correlated with degradation of chlorophylls and phycobiliproteins. Degradation of these pigments in chlorotic cells could provoke increases in SSC signal (Fig. 5).

Based on the results obtained, three phases could be distinguished: (1) during the first hours of herbicide exposure, cells enter an adaptative phase, due to the ineffective photoautotrophic metabolism; (2) the chlorotic subpopulation appears, some cells form chains, and pigment degradation begins, adapting to heterotrophic metabolism; and (3) growth rates of these chlorotic cells reach maximum values at $48-72 \mathrm{~h}$, and individual cells with a low chlorophyll $a$ content begin to appear after this time (Table 2, Fig. 1).

Finally, ecological implications of herbicide addition to natural watercourses could be expected. One of the secondary effects of herbicides in the environment is the promotion of the release of organic matter from soil and sediments, contributing to eutrophication in lakes and watercourses (Margalef 1983). It is well known that natural watercourses are dominated by tolerant species or strains of microalgae (O'Neal and Lembi 1983). This assay showed that cyanobacterial cells are able to change from autotrophic to heterotrophic metabolism in the presence of organic matter and under photoautotrophic stress conditions. This fact implies high respiration rates and a significant decrease in primary production and a dramatic energy unbalance of freshwater ecosystems. 


\section{Acknowledgments.}

This work was funded by a research project from Xunta de Galicia (Spain) (Ref. PGIDT01MAM10302PR). Oscar González-Barreiro and Carmen Rioboo hold a fellowship grant from the Consellería de Presidencia, Xunta de Galicia (Spain), and from the Plan Nacional F.P.U., Ministerio de Educación y Cultura (Madrid, Spain), respectively.

\section{References}

Betancourt L (1997). Producción, purificación y caracterización de ficocianina de Synechococcus sp. 109201 aislada en aguas de Cuba. In: Biología Celular y Molecular. Universidade da Coruña, A Coruña, p 189

Brown TE, Richardson FL, Vaughn ML (1967). Development of red pigmentation in Chlorococcum wimmeri (Chlorophyta: Chlorococcales). Phycologia 6:167-184

Cid A, Herrero C, Torres E and Abalde J (1995). Copper toxicity on the marine microalga Phaeodactylum tricornutum: Effects on photosynthesis and related parameters. Aquat Toxicol $31: 165-174$

Collier JL, Grossman AR (1992). Chlorosis induced by nutrient deprivation in Synechococcus sp Strain PCC 7942: Not all bleaching is the same. J Bacteriol 174:4718-4726

Forrest SC (1990). Pesticides in the tributaries of the St. Lawrence 1987-1988. Program report, St. Lawrence Centre, Montreal, Quebec, Canada

Franqueira DO, M, Torres E, Herrero C, Cid A (2000). Potential use of flow cytometry in toxicity studies with microalgae. Sci Total Environ 247:119-126

Kruglov YVaEIP (1970). Detoxification of simazine by microscope algae. Mikrobiologiya 39:157-160

Lau RH, Mackenzie MM, Doolittle WF (1977). Phycocyanin synthesis and degradation in the blue-green bacterium Anacystis nidulans. J Bact 132:771-778

Margalef R (1983). Limnología. Omega, Barcelona O'Neal SW, Lembi CA (1983). Effect of simazine on photosynthesis and growth of filamentous algae. Weed Sci 31:899-903

Reader S, Marion M, Denizeau F (1993). Flow cytometric analysis of the effects of tri-n-butyltin chloride on cytosolic free calcium and thiol levels in isolated rainbow trout hepatocytes. Toxicology 80:117-129 
Sauer J, Schreiber U, Schmid R, Völker U, Forchhammer K (2001). Nitrogen starvation-induced chlorosis in Synechococcus PCC 7942. Low-level photosynthesis as a mechanism of long-term survival. Plant Physiol 126:233-243

Shapiro HM (1995). Practical flow cytometry, 3rd ed. Wiley-Liss, New York

Siegelman HW, Kycia JH (1978). Algal biliproteins. In: Hellebust JA, Craigie JS (eds) Handbook of phycological methods. Physiological and biochemical methods. Cambridge University Press, Cambridge, pp 71-79

Singh S, Kirkwood RC, Marshall G (1997). Effects of isoproturon on photosynthesis in susceptible and resistant biotypes of Phalaris minor and wheat. Weed Res 37:315-324

Sukenik A, Bennet J, Falkowski P (1988). Changes in the abundance individual apoproteins of light-harvesting chlorophyll a/b-protein complexes of Photosystem I and II with growth irradiance in the marine chlorophyte Dunaliella tertiolecta. Biochim Biophys Acta 932:206-215 